\title{
Suprabasal expression of a dominant- negative RXR $\alpha$ mutant in transgenic mouse epidermis impairs regulation of gene transcription and basal keratinocyte proliferation by RAR-selective retinoids
}

\author{
Xu Feng, Zhen-Hui Peng, Wen Di, Xiao-Yan Li, Cécile Rochette-Egly, ${ }^{1}$ Pierre Chambon, ${ }^{1}$ \\ John J. Voorhees, and Jia-Hao Xiao ${ }^{2}$ \\ Department of Dermatology, University of Michigan, Ann Arbor, Michigan 48109-0314 USA and ${ }^{1}$ LGME/ CNRS, U184 / \\ INSERM, Institut de Génétique et de Biologie Moléculaire et Cellulaire, 67404 Illkirch, France
}

To determine whether 9-cis retinoic acid receptors (RXRs) regulate the biological activity of all-trans retinoic acid (tRA) and its receptors (RARs) in skin, we have targeted a dominant-negative RXR (dnRXR $\alpha$ ) lacking transactivation function AF-2 to differentiated suprabasal keratinocytes in the epidermis of transgenic mice. Driven by the suprabasal-specific keratin-10 gene promoter, expression of dnRXR $\alpha$ severely reduced the ability of RAR-selective ligands tRA and CD367 to induce epidermal mRNA levels of the CRABPII, CRBPI, and CRBPII genes, which contain RA-responsive elements (RAREs) DR1 and/or DR2. It also reduced gene-specific, synergistic induction of CRBPI mRNA by a combination of CD367 and RXR-selective SR11237. Like endogenous $R X R \alpha, \operatorname{dnRXR} \alpha$ in epidermal nuclear extracts from the transgenic mice competitively formed heterodimers with endogenous RAR $\gamma$ on RAREs, suggesting that $\operatorname{dnRXR} \alpha$ impairs retinoid signaling by competing with endogenous $\operatorname{RAR} \gamma-\operatorname{RXR} \alpha$ heterodimers. Histologically, the epidermis of $\operatorname{dnRXR} \alpha$ mice showed no detectable developmental abnormalities. Surprisingly, in adult animals, the suprabasal expression of $\operatorname{dnRXR\alpha }$ significantly reduced the ability of topically applied tRA to stimulate proliferation of undifferentiated keratinocytes in the basal layer of epidermis. RXR-selective ligands alone had no detectable effects on both normal and transgenic mouse epidermis. Accordingly, we suggest that in vivo: (1) in suprabasal keratinocytes, retinoids regulate gene transcription via RAR-RXR heterodimers in which RAR confers a predominant ligand response, whereas RXR AF-2 is required for liganded RAR AF-2 to efficiently trans-activate target genes, and (2) this suprabasal RXR-assisted mechanism indirectly regulates proliferation of basal keratinocytes likely via intercellular signaling.

[Key Words: Retinoids; 9-cis retinoic acid receptor; transgenic mouse; epidermal keratinocytes; gene transcription; cell proliferation]

Received September 4, 1996; revised version accepted November 11, 1996.

Vitamin A (retinol) is an important regulator of epithelial cell homeostasis. All-trans retinoic acid (tRA) is the major biologically active metabolite of vitamin A. Clinically, tRA and related synthetic retinoids are widely used in the therapy of skin disorders such as cystic acne, psoriasis, photoaging skin, and certain epithelial malignancies (for review, see Peck and Di Giovanna 1994). These effects are thought to be mediated by members of two nuclear receptor gene families, retinoic acid receptor (RAR) genes and 9-cis retinoic acid (9cRA) receptor (RXR) genes. Each of the two families comprises three

${ }^{2}$ Corresponding author.

E-MAIL jhxiao@umich.edu; FAX (313) 647-0076. members: $\alpha, \beta$, and $\gamma$ (for review, see Mangelsdorf and Evans 1995; Chambon 1996; Glass 1996; Pfahl and Chytil 1996). In vitro studies have demonstrated that RARs and RXRs form heterodimers (RAR-RXR) or homodimers ( $R X R-R X R$ ) and stimulate gene transcription by binding to cis-acting enhancer elements, termed RAresponsive elements (RAREs), present in gene promoters. The activation function-2 (AF-2) domain at the carboxyl terminus of these receptors confers a ligand-dependent trans-activation function by interacting with transcriptional coactivators. RARs recognize both tRA and 9cRA, whereas RXRs interact exclusively with 9cRA. Therefore, RAR-RXR enables cells to respond to both tRA and 9cRA, whereas RXR-RXR enables the response only to 9cRA. 
Previous studies of knockout mice mutated in RAR $\alpha$ and/or RAR $\gamma$ genes did not reveal any in vivo developmental abnormalities in skin (for review, see Kastner et al. 1995). However, in transgenic mouse models, expression of a dominant-negative (dn) RAR $\alpha(\operatorname{dnRAR} \alpha)$ mutant in undifferentiated keratinocytes in the basal layer of epidermis (basal keratinocytes) perturbed epidermal maturation during embryo development and resulted in prenatal lethality (Saitou et al. 1995). Furthermore, expression of a different dnRAR $\alpha$ in differentiated keratinocytes in the suprabasal layers of epidermis (suprabasal keratinocytes/ showed reduced epidermal barrier function and high neonatal lethality (Imakado et al. 1995). These models suggest the possible involvement of RARs in epidermal organogenesis and differentiation although the molecular events underlying these biological changes remain unknown.

Epidermal keratinocytes, which represent $\sim 95 \%$ of the cell population in epidermis, express RXR $\alpha$ and $-\beta$ and RAR $\alpha$ and $-\gamma$, with RXR $\alpha$ and RAR $\gamma$ being the predominant species distributed throughout epidermal cell layers (for review, see Fisher and Voorhees 1996). When applied externally to normal adult human and mouse skin, pharmacological doses of tRA induce transcription of retinoid-responsive genes including cellular RA binding protein-II (CRABPII), cellular retinol binding protein (CRBP), and early growth response (egr-1) genes in epidermis. tRA also stimulates proliferation of basal keratinocytes and increases the number of differentiated granular keratinocytes within the suprabasal layers in epidermis, resulting in epidermal thickening. However, it is not known whether these epidermal changes result directly from tRA binding to retinoid receptors within epidermal keratinocytes or indirectly from its action in fibroblasts, which are the major cell population in dermis, another major compartment of skin, and are believed to release paracrine factors to affect epidermis (Marks and Furstenberger 1993). On the other hand, the fact that tRA is partly isomerized to 9cRA in skin (Duell et al. 1996) raises the question as to whether in epidermis in vivo, the topical tRA effects in epidermis are mediated by RAR-RXR and/or RXR-RXR as a result of tRA isomerization. In vitro studies have indicated that in most cases, binding of ligands to the RAR partner is predominant and sufficient for RAR-RXR to trans-activate. However, in the absence of RAR ligands, the RXR partner is silent in ligand binding and trans-activation once bound to certain RAREs such as DR5 from the human RAR 32 promoter (Kurokawa et al. 1994; Forman et al. 1995). Therefore, use of RXR-selective retinoids on animal tissues may not allow a full assessment in vivo of whether RXRs participate in retinoid-regulated gene transcription and whether AF-2 of the RXR partner is required for RAR-RXR to trans-activate in response to RAR agonists. Also, previous studies of knockout mice mutated in the RXR $\alpha$ gene did not provide any information about the role of RXR $\alpha$ in skin as a result of early embryo lethality (for review, see Kastner et al. 1995).

In this study, we analyzed the role of RXRs in retinoid signaling in skin in vivo using a $\operatorname{dnRXR} \alpha$ mutant that lacks only AF-2. Under the control of a suprabasal keratinocyte-specific promoter from the bovine keratin-10 gene (Bailleul et al. 1990), $\operatorname{dnRXR} \alpha$ was targeted to differentiated keratinocytes in the suprabasal layers of transgenic mouse epidermis. In several independent lines of transgenic mice expressing $\operatorname{dn} R X R \alpha$, we found that the stimulatory effects of RAR agonists on transcription of retinoid-responsive genes were markedly reduced in epidermis. Although the $\operatorname{dnRXR} \alpha$ mice appeared to have normal epidermal development, the stimulatory effects of the RAR agonists on proliferation of epidermal basal keratinocytes were markedly reduced in the adult transgenic mice. Thus, our study provides for the first time the in vivo evidence that in suprabasal keratinocytes, retinoids regulate gene transcription via RAR-RXR in which RAR confers a predominant ligand response, whereas RXR AF-2 is required for liganded RAR AF-2 to efficiently trans-activate. Our data also suggest that the activity of RAR-RXR in suprabasal keratinocytes indirectly stimulates proliferation of basal keratinocytes via intercellular signaling.

\section{Results}

Characterization of $d n R X R \alpha$ in receptor dimerization and DNA binding

As RXR $\alpha$ and RAR $\gamma$ are two predominant retinoid receptor forms in epidermis, we selected an RXR $\alpha$ mutant to interfere with endogenous RXR and/or RAR activity in this tissue. This mutant, termed $\operatorname{dnRXR} \alpha$, contains a carboxy-terminal deletion between amino acid positions 449 and 467 (Fig. 1A). This deletion impairs the AF-2 but not ligand-binding nor dimerization functions of $\mathrm{RXR} \alpha$ (Nagpal et al. 1993; Zhang et al. 1994). dnRXR $\alpha$ has been shown to dominantly inhibit ligand-dependent trans-activation of RARE-containing reporter genes by wild-type RAR-RXR in cultured cells (Durand et al. 1992; 1994; Xiao et al. 1995). It has also been shown that in vitro transcribed and translated $\operatorname{dnRXR} \alpha$ binds to a synthetic thyroid hormone response element (TRE) in the form of RAR $\beta-d n R X R \alpha$ or $\operatorname{dnRXR} \alpha-\operatorname{dnRXR} \alpha$ (Zhang et al. 1994). However, the ability of $\operatorname{dnRXR} \alpha$ in either heterodimerization with RAR $\gamma$ on a broad spectrum of naturally occurring RAREs of types DR1, DR2, and DR5 or homodimerization with itself on DR 1 has not been documented. To do this, expression vectors for wild-type $\mathrm{RXR} \alpha$ or $\operatorname{dnRXR} \alpha$ were transfected together with or without those for RAR $\gamma$ into cultured keratinocytes. Immunological gel mobility shift assays were performed with nuclear extracts prepared from these transfected cells using oligonucleotide probes containing the DR5 from the human RAR $\beta 2$ gene, the DR2 from the mouse CRBPI gene, or the DR1 from the rat CRBPII gene.

Because levels of overexpressed receptors far exceed those of endogenous receptors in transfected keratinocytes (Xiao et al. 1995) and because very low amounts 2 $\mu \mathrm{g}$ ) of nuclear extracts from these cells were used, receptor-DNA complexes detected by the assays pertain to 
A

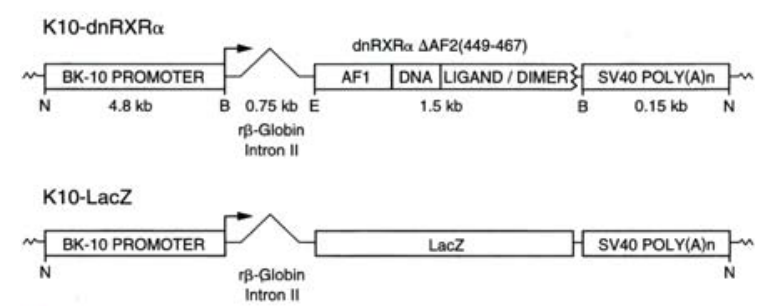

B

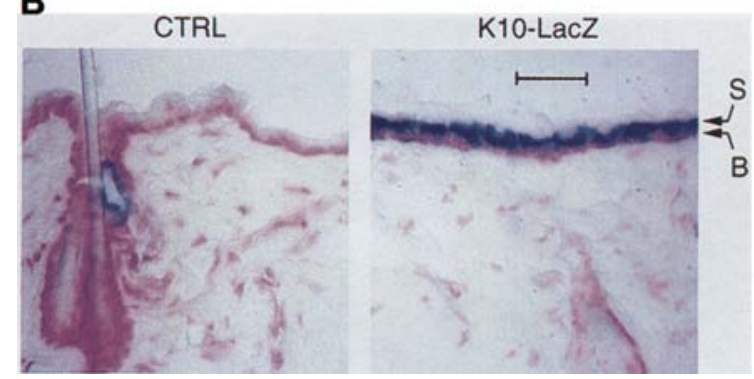

Figure 1. Targeting expression of transgenes to suprabasal keratinocytes in mouse epidermis. (A) Structure of suprabasal keratinocyte-specific expression vectors $\mathrm{K} 10-\operatorname{dnRXR} \alpha$ and $\mathrm{K} 10$ $l a c Z$ used in preparation of transgenic mice. The arrowhead indicates transcription direction under the control of the bovine keratin 10 (BK-10) gene promoter. The folded line represents intron II from the rabbit $\beta$-globin gene. $\operatorname{dnRXR} \alpha$ cDNA lacks AF-2, but retains functional domains as indicated. (AF1) Activation function-1; (DNA) DNA-binding domain; (LIGAND) ligand-binding domain; (DIMER) dimerization domain; [SV40 POLY|A|n] a polyadenylation signal sequence from SV40. The size of each DNA fragment is shown below the corresponding structure. Restriction sites [(N) NotI; (B) BglII; [E EcoRI] are also indicated below the constructs. $(B)$ Specific expression of lac $Z$ under the control of the BK-10 promoter in epidermal suprabasal keratinocytes. Punch biopsies $(4 \mathrm{~mm})$ were taken from the dorsal skin of adult control (CTRL) or K10-lacZ mice, and frozen sections $(5 \mu \mathrm{m})$ were prepared. $\beta$-Galactosidase activity in keratinocytes (blue) in the suprabasal layers $(S)$ of epidermis was revealed by X-Gal staining of the sections. The sections were briefly counterstained with nuclear fast red. Note that there is no specific blue staining of undifferentiated keratinocytes in the basal layer (B). Bar, $50 \mu \mathrm{m}$.

overexpressed receptors. As shown in Figure 2A, RAR $\gamma$ $\operatorname{dnRXR} \alpha$ (lane 8) was formed as efficiently as RAR $\gamma$ RXR $\alpha$ (lane 2) when DR5 was used as a probe. Mutations in the half-sites of DR5 abolished formation of these dimers (lanes 1 and 7). Like RAR $\gamma-\operatorname{RXR} \alpha$, RAR $\gamma$ $\operatorname{dnRXR} \alpha$ was supershifted by monoclonal antibodies against the DE region of $\mathrm{RXR} \alpha(\mathrm{RXR} \alpha-\mathrm{Ab}$, lane 10$)$ or the amino terminus of RAR $\gamma(\operatorname{RAR} \gamma-\mathrm{Ab}$, lane 11) and a polyclonal antibody against RARs (RAR-Ab, lane 12). However, monoclonal antibody RXR-Ab, which recognizes a different epitope within the DE region of all three RXR members, did not supershift but rather reduced slightly the formation of RAR $\gamma-\operatorname{dnRXR} \alpha$ (lane 9), in contrast to RAR $\gamma-R X R \alpha$ that was supershifted by this antibody (lane 3). Similar results were obtained when DR2 or DR1 was used as a probe (Fig. 2B,C). Interestingly, formation of RAR $\gamma$-dnRXR $\alpha$ was more strongly inhibited by RXRAb on DR2 (lane 9, Fig. 2B) and DR1 (lane 9, Fig. 2C) than DR5 (lane 9, Fig. 2A).

dnRXR $\alpha$ was also analyzed for its ability in ligandsensitive homodimerization (Fig. 2D). Like wild-type $\operatorname{RXR} \alpha$ (lanes 1 and 2), $\operatorname{dnRXR} \alpha$ was able to form homodimers on DR1 (lane 6), and this formation was significantly enhanced by 9cRA (lane 7). Thus, the removal of the 19-amino-acid carboxyl terminus from $\operatorname{RXR} \alpha$ does not affect its ligand-sensitive homodimerization function. Interestingly, like DNA-bound $\operatorname{RAR} \gamma-\operatorname{dnRXR} \alpha$, formation of $\operatorname{dnRXR} \alpha-\operatorname{dnRXR} \alpha$ on DR1 was significantly reduced by RXR-Ab (lane 8 ), whereas $R X R \alpha-A b$ supershifted this complex efficiently (lane 9). In comparison, DR1-bound RXR $\alpha-R X R \alpha$ was supershifted by both RXR-Ab (lane 3) and RXR $\alpha-A b$ (lane 4). These observations indicate that interaction between RXR-Ab and $\operatorname{dnRXR} \alpha$-containing dimers, that is, $\operatorname{RAR} \gamma-\operatorname{dnRXR} \alpha$ and $\operatorname{dnRXR} \alpha-\operatorname{dnRXR} \alpha$, affects their ability to bind DNA, in marked contrast to RAR $\gamma-\operatorname{RXR} \alpha$ and $\operatorname{RXR} \alpha-\operatorname{RXR} \alpha$, respectively. Thus, this antibody can be used to distinguish receptor dimers formed with $\operatorname{dnRXR} \alpha$ from those with RXR $\alpha$.

The above DNA-binding study suggests that $\operatorname{dnRXR} \alpha$ is capable of binding to a variety of RAREs as either $\operatorname{RAR} \gamma-\operatorname{dnRXR} \alpha$ or $\operatorname{dnRXR} \alpha-\operatorname{dnRXR} \alpha$. Thus, if RARRXR is the major mediator of retinoid activity on target genes in mouse epidermis, there would be two outcomes from targeting expression of this mutant to the epidermis: (1) If RXR $\alpha$ AF-2 is required for the full function of RAR-RXR, expression of dnRXR $\alpha$ would reduce the ability of retinoids, especially RAR-selective retinoids, to induce transcription of target genes as a result of competitive formation of RAR-dnRXR $\alpha$ on RAREs; and (2) if $\mathrm{RXR} \alpha \mathrm{AF}-2$ is dispensable, no changes in the response of epidermis to retinoids would be observed. However, if RXR-RXR mediates retinoid effects in epidermis, RXRselective retinoids alone would show typical retinoid effects, and expression of $\operatorname{dnRXR} \alpha$ would reduce these effects.

\section{Construction of suprabasal keratinocyte-specific expression vectors carrying $\operatorname{dn} R X R \alpha$}

To target expression of $\operatorname{dnRXR} \alpha$ to the mouse epidermis, we constructed an expression vector K10-dnRXR $\alpha$ (Fig. 1A) using the bovine keratin-10 gene promoter. This fulllength promoter has been shown previously to drive expression of many transgenes specifically in differentiated keratinocytes within the suprabasal layers, but not in undifferentiated keratinocytes in the basal layer of mouse epidermis (Bailleul et al. 1990; Werner et al. 1993; Auewarakul et al. 1994). To efficiently produce mRNA of interest, intron II from the rabbit $\beta$-globin gene and an RNA polyadenylation signal from the SV40 virus were included in the vector. The parental vector was verified for its ability to direct expression of the bacterial lacZ gene in skin. Transgenic mice carrying K10-lacZ showed $\beta$-galactosidase activity specifically in suprabasal kera- 
Figure 2. Immunological gel mobility shift analysis of the ability of $\operatorname{dnRXR} \alpha$ to form either heterodimers with RAR $y$ on DR5 $|A|$, DR2 $(B)$, and DR1 $(C)$ or homodimers with itself on DR1 (D). Cultured keratinocytes were transfected with a combination of expression vectors for RAR $\gamma, \operatorname{RXR} \alpha$, or $\operatorname{dnRXR} \alpha$ as shown below each gel. Nuclear extracts from these cells $(2 \mu \mathrm{g})$ were incubated with ${ }^{32} \mathrm{P}$-labeled probes containing wild-type (wt) or mutated (m) DR5, DR2, or $\mathrm{DR} 1$ as indicated at the top. Antibodies were added during postincubation as shown immediately above the gels. Types of receptor dimeric complexes identified by antibody supershifting are labeled on both sides of the gels. To stimulate formation of RXR $\alpha-$ $\mathrm{RXR} \alpha, 1 \mu \mathrm{M} 9 \mathrm{cRA}$ was included in the binding reactions, except for those of lanes 1 and 6 in $D$.
A

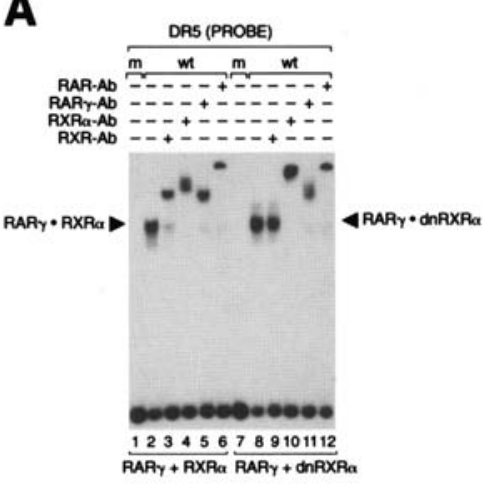

C

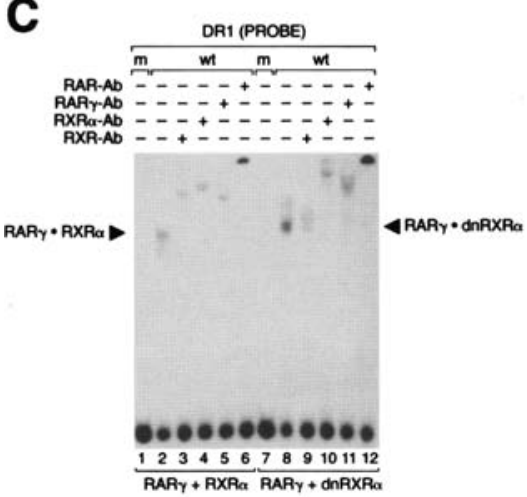

B

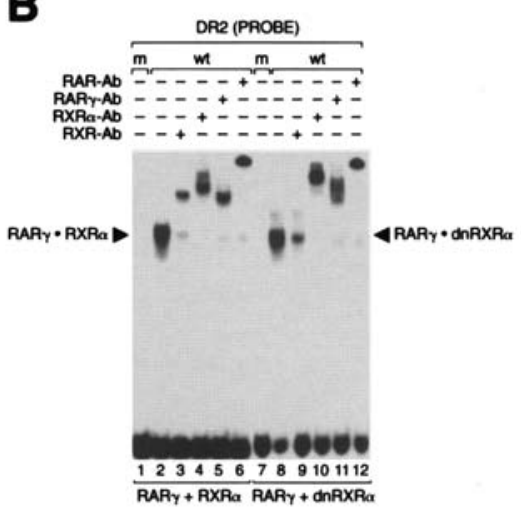

D

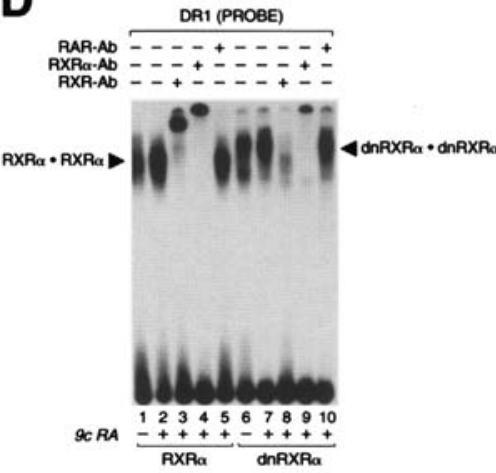

tinocytes, but not basal keratinocytes, which are located immediately above the dermis (Fig. 1B).

Specific expression of $\operatorname{dnRXR} \alpha \mathrm{mRNA}$ in the epidermis of transgenic mice

DNA fragments, $\mathrm{K} 10-\mathrm{dnRXR} \alpha$, were microinjected into fertilized mouse oocytes and transplanted into pseudopregnant female mice (see Materials and Methods). Birth was closely monitored. Newborn mice were screened for the presence of K10-dnRXR $\alpha$ by PCR genotyping using primers specific to the bovine $\mathrm{K} 10$ promoter and $\operatorname{dnRXR} \alpha$ cDNA. Of these mice, $11 \%$ were identified as $\mathrm{K} 10-\mathrm{dnRXR} \alpha$ carriers and did not show developmental abnormalities in skin. We outbred four of these transgenic founders and examined their F1-F4 heterozygous progeny in detail. As shown in Figure 3A, animals from these founder lines carry 5-100 copies of the K10$\operatorname{dnRXR} \alpha$ construct (lanes 2-5), as determined by Southern blotting analysis. To determine whether these mice express $\operatorname{dnRXR} \alpha$, total RNA was extracted from the epidermis of these mice and analyzed by Northern blotting. A 1.9-kb mRNA corresponding to $\operatorname{dnRXR} \alpha$ was detected in transgenic mice (Fig. 3B, lanes 2-5), but not in nontransgenic littermates (lane 1). Ratios between $\operatorname{dnRXR} \alpha$ and endogenous RXR $\alpha$ vary from 1.5 to 3.5 among these mouse lines. We have also examined tissue distribution of $\operatorname{dnRXR} \alpha$ mRNA. As shown in Figure $3 \mathrm{C}, \operatorname{dnRXR} \alpha$ mRNA is expressed at high levels in epidermis (lane 1) and to a much lesser extent in tongue (lane 2), but not in other tissues such as liver, heart, lung, kidney, and intestine (lanes 3-7).

Reduced dose-dependent induction of the CRABPII, $C R B P I$, and CRBPII genes by all-trans retinoic acid in the epidermis of $d n R X R \alpha$ mice

To know whether expression of $\operatorname{dnRXR} \alpha$ led to changes in epidermal responses to retinoids, tRA was applied topically to skin of heterozygous transgenic mice from three independent $\operatorname{dnRXR} \alpha$ lines or nontransgenic controls. At $20 \mathrm{hr}$ after treatment, mice were sacrificed and epidermal biopsies were taken immediately. Total mRNA was extracted from the biopsies and analyzed by Northern blotting using CRABPII cDNA as a probe. We observed $40-70 \%$ decreases in induction of CRABPII mRNA by tRA in transgenic mice as compared with control mice, with mice from line 4539 being the most severely affected, in correlation with relative levels of $\operatorname{dnRXR} \alpha$ mRNA expressed in these lines (Fig. 3D) Thus, inhibition of the tRA effect depends on the expression levels but not on the chromosomal integration sites of the K10-dnRXR $\alpha$ transgene. Such inhibition was only slightly enhanced in homozygous 4539 mice (high $\operatorname{dnRXR} \alpha$ expressors) because the ratio of $\operatorname{dnRXR} \alpha$ to endogenous RXR $\alpha$ was increased from 3.5 in the heterozygotes to only $\sim 4.3$ in the homozygotes (data not shown). This limited increase is probably caused by the limited 

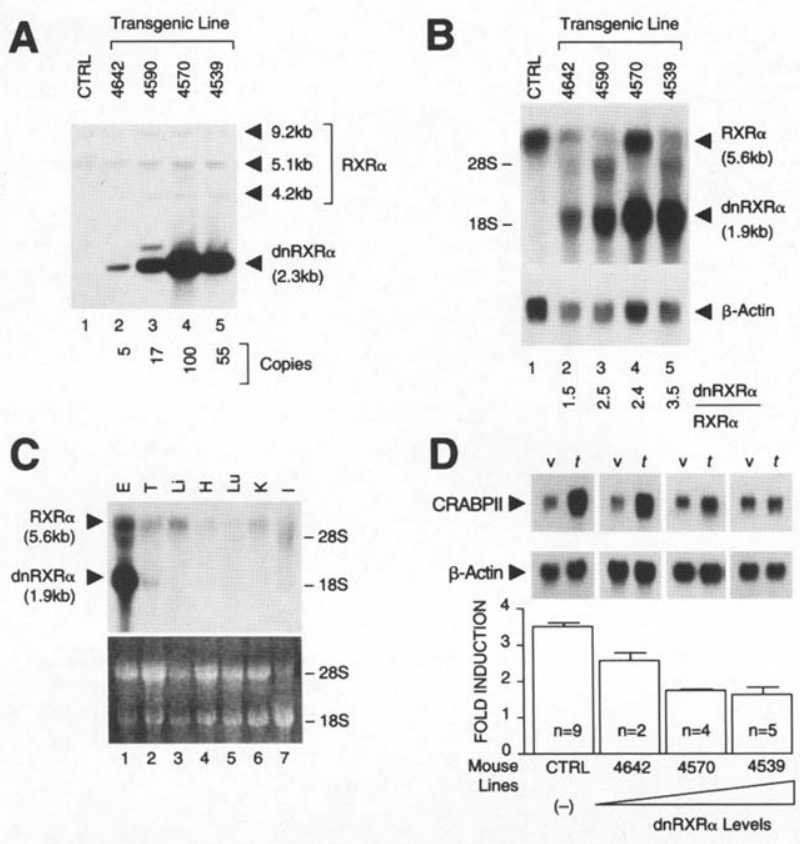

Figure 3. Characterization of transgenic mice carrying K10 $\operatorname{dnRXR} \alpha$. (A) Southern blotting analysis of genomic DNA (10 $\mu \mathrm{g}$ ) from $\operatorname{dnRXR} \alpha$ mice of independent lines (Tg4642, Tg4590, Tg4570, and Tg4539) and a control mouse (CTRL). Signals and sizes corresponding to endogenous $\mathrm{RXR} \alpha$ gene or $\operatorname{dn} \mathrm{RXR} \alpha$ transgene are indicated on the left. The estimated copy number of the dnRXR $\alpha$ transgene in mouse genome is shown immediately below the blot. Genomic DNA from mouse tails was digested with $B g I I I$, which releases the dnRXR $\alpha$ cDNA region (Fig. 1A). (B) Northern blotting analysis of epidermal total RNA (20 $\mu \mathrm{gg}$ from a control mouse and $\operatorname{dnRXR} \alpha$ mice. mRNA signals corresponding to the endogenous RXR $\alpha$ gene or $\operatorname{dn} R X R \alpha$ transgene are indicated. mRNA ratios between $\operatorname{dnRXR} \alpha$ and endogenous $\operatorname{RXR} \alpha$ are shown below the blot. The control signals ( $\beta$ actin) show variation in the amounts of RNA loaded. (C) Northern blotting analysis of total RNA from different tissues of a dnRXR $\alpha$ mouse. (Top) Autoradiography of a Northern blot containing total RNA $(20 \mu \mathrm{g})$ from epidermis $(\mathrm{E})$, tongue $(\mathrm{T})$, liver $(\mathrm{L})$, heart $(\mathrm{H})$, lung $(\mathrm{Lu})$, kidney $(\mathrm{K})$, and intestine $(\mathrm{I})$. (Bottom) The ethidium bromide-stained agarose gel before blotting, which serves as an RNA quality control. Positions of $28 \mathrm{~S}$ and $18 \mathrm{~S}$ ribosomal RNA are indicated, $\mathrm{mRXR} \alpha \mathrm{cDNA}$ was used as a probe in these analyses. $(D$, top $)$ Autoradiography of Northern blots containing epidermal RNA $(20 \mu \mathrm{g})$ from $\operatorname{dnRXR} \alpha$ mice of independent lines and a nontransgenic control mouse (CTRL), which were treated topically with vehicle (v) or 80 nmoles tRA (t). (Bottom) A bar graph showing average fold induction of CRABPII mRNA in tRA-treated mice vs. vehicle-treated mice from the same line. Relative mRNA levels of $\operatorname{dnRXR} \alpha$ vs. $\operatorname{RXR} \alpha$ in the $\operatorname{dnRXR} \alpha$ mouse lines are indicated below the $x$-axis. $(n)$ Number of mice from each line used in the treatment. Standard errors are indicated on the top of bars.

availability of transcription factors for the high copy number of the bovine K10 promoter in the epidermal cells of transgenic mice.

F1-F4 heterozygous offspring from mouse line 4539 (high dnRXR $\alpha$ expressors) was further analyzed in detail for regulation of CRABPII in epidermis under acute $(20$ hr) and chronic (4 days, one application per day) treatments with topical tRA. In the acute treatment, tRA induced CRABPII mRNA levels much less efficiently in the dnRXR $\alpha$ mice than in the control mice at doses applied (Fig. 4A,B). The inhibitory effect brought by $\operatorname{dnRXR} \alpha$ over CRABPII was also seen in the chronic treatment. Again in correlation with levels of $\operatorname{dnRXR} \alpha$, a moderate reduction in the tRA effect was observed with mice from line 4570 (low dnRXR $\alpha$ expressors) (Fig. 4B). To know whether the inhibitory effects of $\operatorname{dnRXR} \alpha$ also extended to other retinoid-responsive genes, epidermal RNA from the tRA-treated mice was analyzed using CRBP-I and -II cDNA as probes. As shown in Figure $4 A, C$, and $D$, the effects of tRA on these two genes were reduced significantly in the $\operatorname{dnRXR} \alpha$ mice as compared with the control mice. As in the case with CRABPII, the inhibitory effects brought by $\operatorname{dnRXR} \alpha$ on these two genes were larger in the chronic treatment than in the acute treatment.

dnRXR $\alpha$ reduced the response of CRABPII, CRBPI, and CRBPII genes to retinoid receptor-selective agonists

As tRA is isomerized in part to 9cRA in epidermis (Duell et al. 1996), it raises the question of whether tRA exerts its effects on the CRABPII, CRBPI, and CRBPII genes via the pathways mediated by RAR-RXR and/or RXR-RXR as a result of 9cRA formation. To answer this question, we applied topically the RAR-selective synthetic ligand CD367 at suboptimal doses, RXR-selective synthetic ligand SR11237, or a combination of these two ligands to dnRXR $\alpha$ mouse skin. After $20 \mathrm{hr}$, epidermal RNA was extracted and analyzed by Northern blotting. As shown in Figure 4E and F, CD367 but not SR11237 alone induced CRABPII, CRBPI, and CRBPII mRNA significantly in control mice, indicating that induction of these genes by retinoids is mediated by the RAR-, but not the RXRdependent pathways. Under the same conditions, induction of these genes was $\sim 50-60 \%$ lower in the $\operatorname{dnRXR} \alpha$ mice, suggesting that RAR-RXR is the mediator of the RAR-dependent pathway and that the integrity of RXR $\alpha$ AF-2 is required for RAR-liganded RAR-RXR to efficiently trans-activate. In the control mice, SR11237 synergistically enhanced CD367-induced transcription of CRBPI. This synergism was observed only when CD367 was used at these suboptimal doses. No such synergism was observed with CRABPII and CRBPII even when other suboptimal doses of CD367 were used. In the $\operatorname{dnRXR} \alpha$ mice, the CD367-SR11237 synergism on CRBPI was reduced significantly. The residual retinoid induction of these genes may be contributed by the residual activity of trans-activation-deficient $R A R \gamma$ $\operatorname{dnRXR} \alpha$ and/or the activity of remaining RAR $\gamma-\operatorname{RXR} \alpha$ in suprabasal keratinocytes (see Fig. 7, below). Alternatively, as epidermal samples analyzed by Northern blotting contain RNA from both suprabasal and basal keratinocytes, the residual induction might be caused in part by cell types not expressing the transgene, such as basal keratinocytes in the dnRXR $\alpha$ mice. 
Figure 4. Reduced tRA effects on transcription of CRABPII, CRBPI, and CRBPII genes in the epidermis of adult $\operatorname{dnRXR} \alpha$ mice. (A) Autoradiography of representative Northern blots containing epidermal RNA from nontransgenic control mice (CTRL, lanes 1-5) and $\operatorname{dnRXR} \alpha$ transgenic mice from line 4539 ( $\mathrm{Tg} 4539$, lanes 6-10), which were treated topically for 1 day $(20$ hr) with vehicle (VEH, lanes 1 and 6) or tRA at doses indicated above the blots. $(B-D)$ Quantitative comparison of the dosedependent effects of tRA on induction of CRABPII $(B)$, CRBPI $(C)$, and CRBPII $(D)$ mRNA in control mice with those in $\operatorname{dnRXR} \alpha$ mice of lines 4539 or 4570 . Mice received either acute $(1 \mathrm{~d}, 20 \mathrm{hr})$ or chronic (4d, 4 days) treatments with topical tRA. The $y$-axis represents relative mRNA levels in tRA-treated mice expressed as fold induction over the basal level in vehicletreated mice. Each data point is an average value from a group of mice with a size $(n)$ as indicated. The $x$-axis shows the amount of tRA applied using a log scale. (E) Autoradiography of representative Northern blots containing epidermal RNA from control (CTRL, lanes 1-4) or $\operatorname{dnRXR} \alpha$ mice (Tg4539, lanes 5-8), which were treated topically with vehicle (V), 80 nmoles RXRselective SR11237 (SR), 0.32 nmole RARselective CD367 (CD), or SR11237 plus CD367 (CD + SR). Epidermal RNA (20 $\mu \mathrm{g})$ from each treated mouse was analyzed by Northern blotting using CRABPII, CRBPI, CRBPII, and $\beta$-actin cDNA as probes. $(F)$ Bar graph showing the relative levels of CRABPII, CRBPI, and CRBPII mRNA in the treated mice. Types of ligands used and genes analyzed are indicated below the $x$ axis.
A
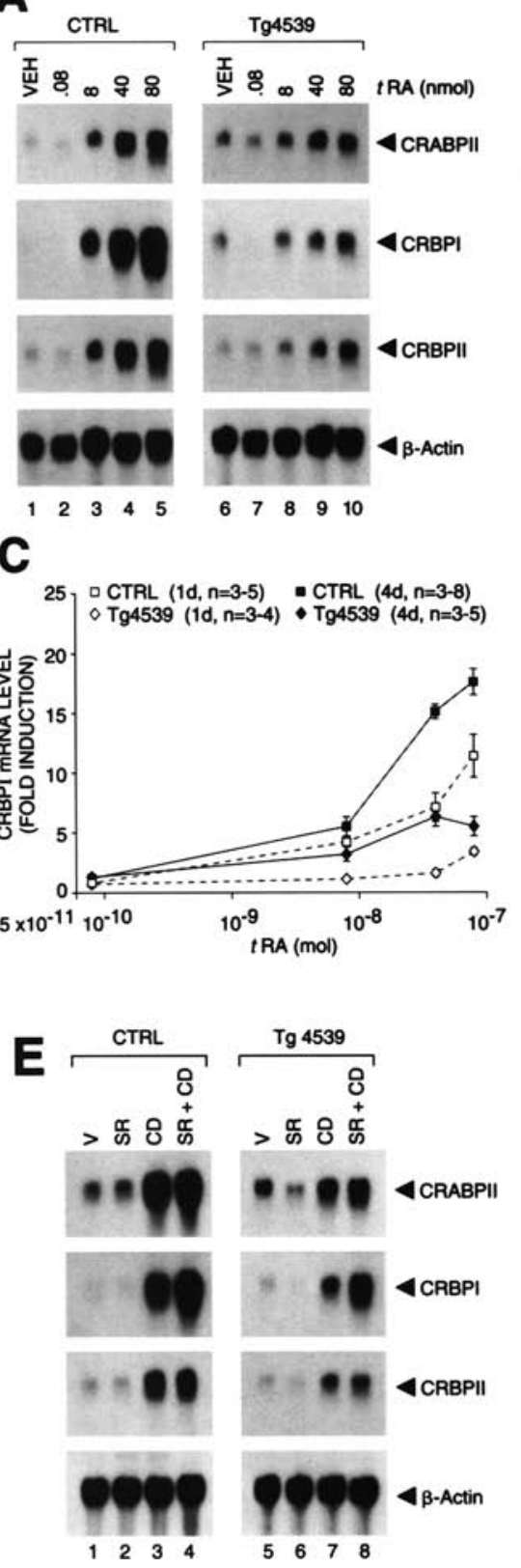

B

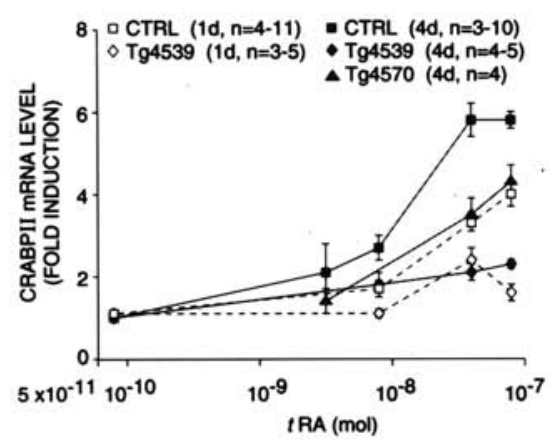

D

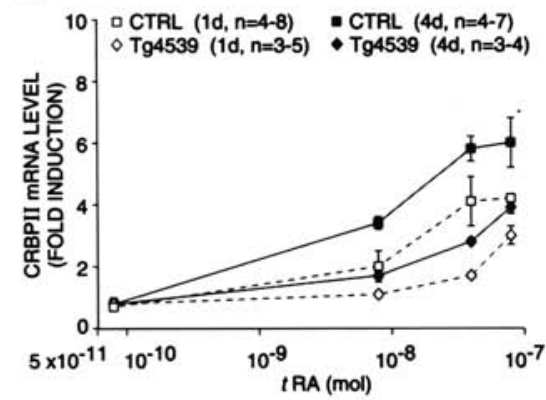

$\mathbf{F}$

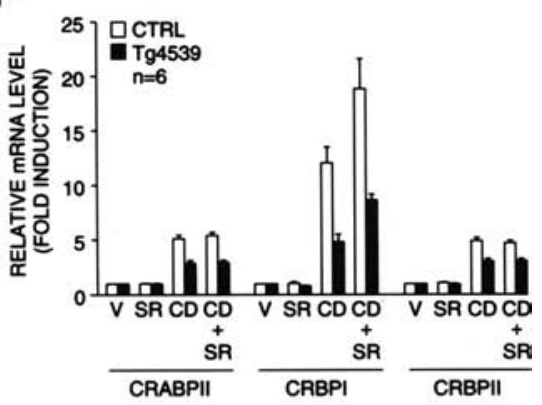

$d n R X R \alpha$ reduced the effects of all-trans retinoic acid on keratinocyte proliferation and differentiation in epidermis

tRA induces epidermal hyperplasia characterized by epidermal thickening, hyperproliferation of basal keratinocytes, and expansion of terminally differentiated keratinocytes containing keratohyalin granules, that is, granular keratinocytes. To examine whether $\operatorname{dnRXR} \alpha$ affects the ability of tRA to induce epidermal hyperplasia, skin of the dnRXR $\alpha$ mice was treated topically with different doses of tRA for 4 days and examined at histological levels. Nontransgenic littermates were used as controls. As shown in Figure 5, tRA dose-dependently caused epidermal thickening in the controls. It also increased epidermal cellularity, the volume of cells, space between keratinocytes, and granular keratinocyte layers. Labeling of the epidermis with BrdU revealed a $53 \%$ increase in proliferating basal keratinocytes in control mice treated with 8 nmoles tRA for 4 days (Fig. 6). However, in the $\operatorname{dnRXR} \alpha$ mice from lines 4539 and 4570, the ability of tRA to induce epidermal thickening was significantly reduced, as compared with the control littermates (Fig. 5A,B). Induction of basal keratinocyte proliferation by 8 nmoles tRA in the $\operatorname{dnRXR} \alpha$ mice was significantly lower than that in the controls, although there was no significant difference in proliferation rate among the mice treated with vehicle (Fig. 6). On the other hand, 

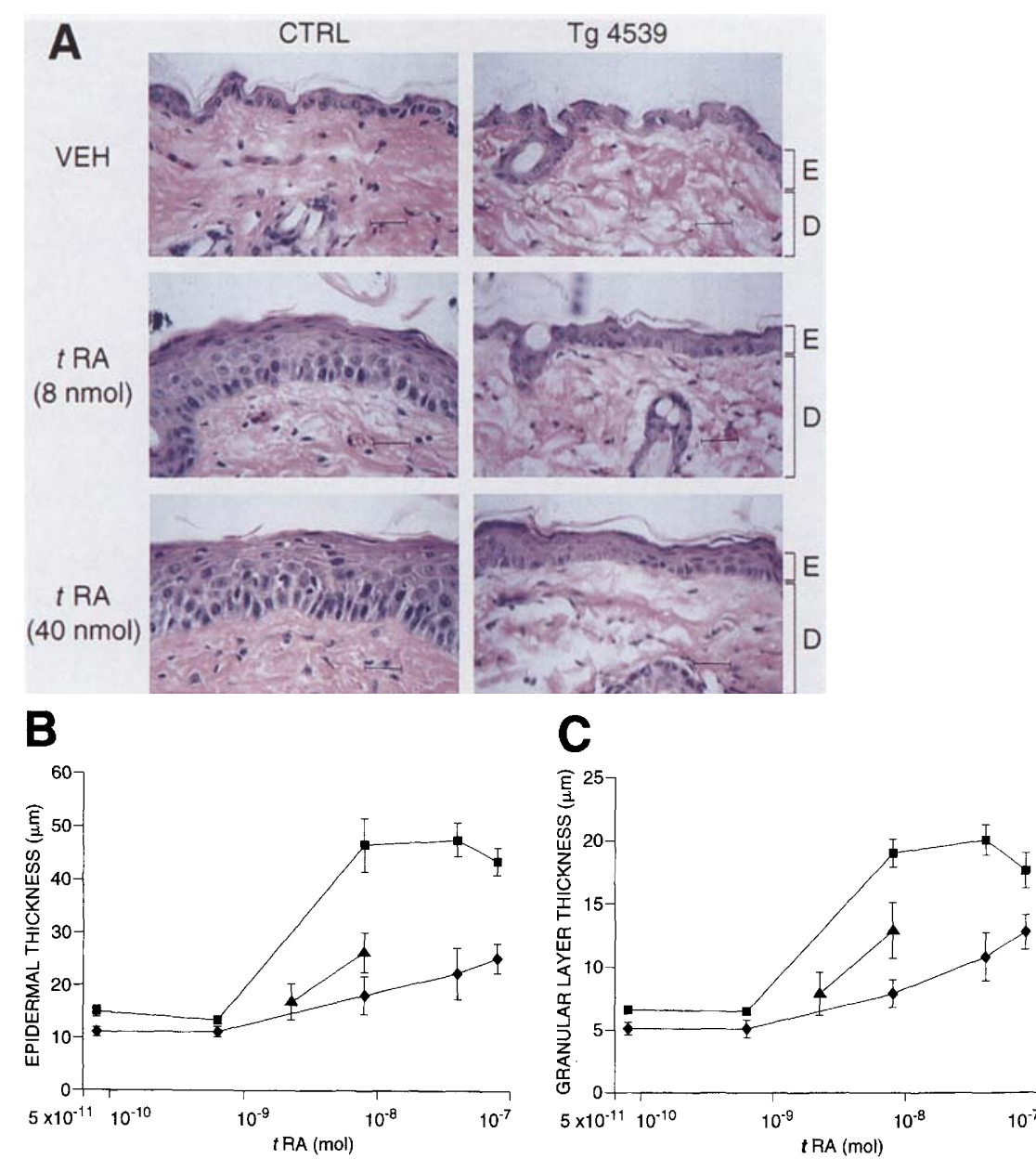

Figure 5. Reduced epidermal responses to tRA in $\operatorname{dnRXR} \alpha$ mice at histological levels. Skin of control (CTRL) or transgenic mice of line 4539 ( $\mathrm{Tg} 4539$ ) was treated topically with vehicle (VEH) or tRA at indicated doses for 4 days. (A) Micrographs of sections of mouse dorsal skin showing lower degrees of epidermal thickening, spongiosis, and cellular enlargement in $\operatorname{dnRXR} \alpha$ mice (right) as compared with control littermates (left). The sections $(5 \mu \mathrm{m})$ were stained with hemotoxylin-eosin. Bar, $25 \mu \mathrm{m}_{\text {; }}$ (E) epidermis; (D) dermis. (B) Reduced dosedependent induction of epidermal thickness by tRA in $\operatorname{dnRXR} \alpha$ mice. $(C)$ Reduced dosedependent induction of the thickness of granular cell layers by tRA in $\operatorname{dnRXR} \alpha$ mice. $(B, C)(\boldsymbol{\square})$ CTRL $(n=4-6) ;(\mathbf{A})$ Tg4570 $(n=3-4) ;(\bullet) \operatorname{Tg} 4539(n=4-8)$.
$\operatorname{dnRXR} \alpha$ also reduced the ability of tRA to increase the thickness of granular keratinocyte layers (Fig. 5C). Similar results were obtained with RAR-selective CD367, whereas RXR-selective agonist SR11237 had no effects on both control and $\operatorname{dnRXR} \alpha$ mice (data not shown). The tRA-induced epidermal changes were less pronounced in the 4570 mice (low $\operatorname{dnRXR} \alpha$ expressors), as compared with the 4539 mice (high $\operatorname{dnRXR} \alpha$ expressors) (Figs. $5 B, C$, and $6 B)$.

\section{Identification of $\operatorname{dn} R X R \alpha$ present in keratinocytes of transgenic mouse epidermis as $R A R \gamma$ - dnRXR $\alpha$ heterodimers}

As the epidermis of the $\operatorname{dnRXR} \alpha$ mice showed reduced responses to $\mathrm{RAR}$-selective retinoids, it raised the question of whether $\operatorname{dnRXR} \alpha$ is able to dimerize with endogenous RARs to form RAR $\gamma-\operatorname{dnRXR} \alpha$ and compete with endogenous $\operatorname{RAR} \gamma-\mathrm{RXR} \alpha$ for binding to RAREs in epidermal keratinocytes. We examined keratinocyte nuclear extracts from the epidermis of transgenic heterozygotes and their nontransgenic littermates by immunological gel mobility supershift assays. As shown in Figure 7, formation of complexes with DR5 was observed with the extracts from the control (lane 2) and the trans- genic mice (lane 8). Mutation of both half-sites in DR5 abolished the complex formation (lanes 1 and 9). These complexes correspond to $\operatorname{RAR} \gamma-\operatorname{RXR} \alpha$ in the control mice and comigrating RAR $\gamma-\operatorname{dnRXR} \alpha$ and $\operatorname{RAR} \gamma-\operatorname{RXR} \alpha$ in the $\operatorname{dnRXR} \alpha$ mice, respectively. RXR-Ab efficiently supershifted endogenous RAR $\gamma-\operatorname{RXR} \alpha$ in both mice, but not $\operatorname{RAR} \gamma-\mathrm{dnRXR} \alpha$ in the transgenic mice. In the transgenic mice, increasing amounts of RXR-Ab inhibited binding of RAR $\gamma-\operatorname{dnRXR} \alpha$ to DR5, consistent with the properties of $\operatorname{RAR} \gamma-\operatorname{dnRXR} \alpha$ overexpressed in cultured keratinocytes as described above (Fig. 2). Note that a low amount $(0.5 \mu \mathrm{l})$ of RXR-Ab was sufficient to supershift $\operatorname{RAR} \gamma-\operatorname{RXR} \alpha$ in the $\operatorname{dnRXR} \alpha$ mice (lane 10) because increasing amounts of this antibody did not further increase the level of the antibody-associated RAR $\gamma-\operatorname{RXR} \alpha$ complexes (RAR $\gamma-R X R \alpha-R X R-A b$, lanes 11-12). Quantitation of these complexes by PhosphorImager indicates that the ratio between $\operatorname{RAR} \gamma-\operatorname{dnRXR} \alpha$ and $\operatorname{RAR} \gamma-\operatorname{RXR} \alpha$ in the $\operatorname{dnRXR} \alpha$ mice is $\sim 2.5: 1$. As expected, both $\operatorname{RAR} \gamma-$ $\operatorname{RXR} \alpha$ and RAR $\gamma-\mathrm{dnRXR} \alpha$ were supershifted by $\operatorname{RXR} \alpha-$ $A b$, which reacts with $\operatorname{RXR} \alpha$ and $\operatorname{dnRXR} \alpha$ in a similar manner (Fig. 2), and RAR $\gamma$-Ab. Similar binding patterns were observed with these extracts when DR1 was used as a probe. No $\operatorname{dnRXR} \alpha$-containing RXR homodimers were detected (data not shown). These data indicate that 


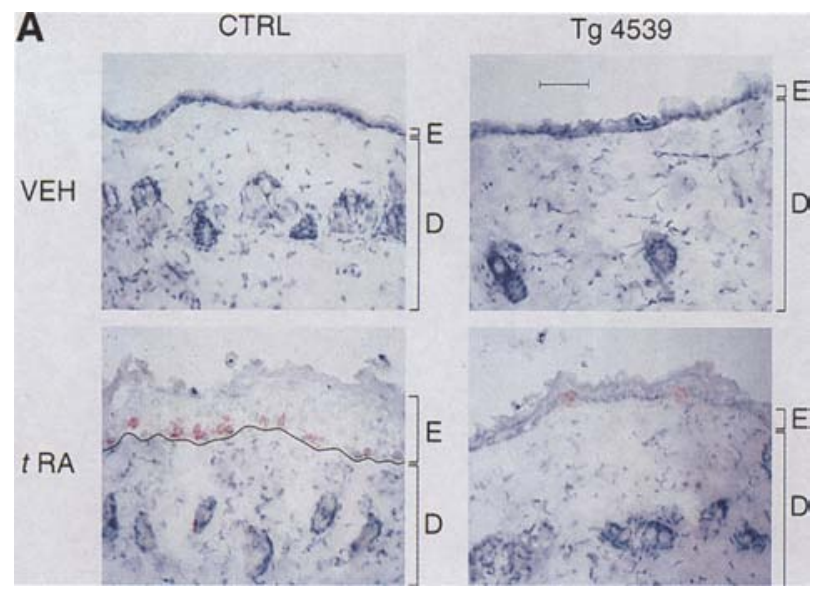

B

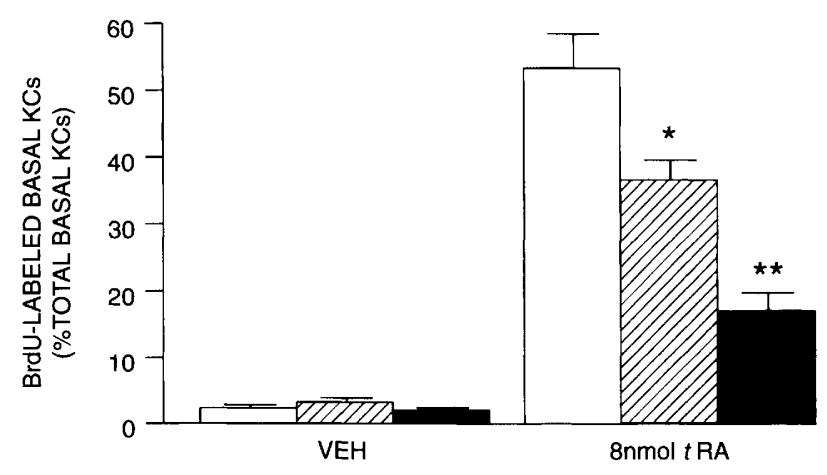

Figure 6. Expression of $\operatorname{dnRXR} \alpha$ in suprabasal keratinocytes reduces stimulatory effects of tRA on proliferation of basal keratinocytes in transgenic mouse epidermis. $(A)$ Representative micrographs showing BrdU-labeled basal keratinocytes (red) in dorsal skin sections from adult transgenic mice of line 4539 (Tg4539) and nontransgenic control littermates (CTRL) treated with vehicle (VEH) or tRA for 4 days. Bar, $50 \mu \mathrm{m}$; (E) epidermis; (D) dermis. A solid line indicates epidermal-dermal junction. (B) Bar graph showing relative scores of BrdU-labeled basal keratinocytes in the epidermis of transgenic [Tg4539 (solid bar; $n=6-$ 7) and $\operatorname{Tg} 4570$ (hatched bar; $n=4)]$ and control mice (open bar; $n=6$ ). The number of BrdU-labeled basal keratinocytes (KCs) are expressed as percentage of total basal keratinocytes in scored areas. $\left(^{*}\right)$ and $\left({ }^{*}\right) \mathrm{P}$ value $<0.0001$ between the transgenic and the control mice, as determined by Fisher's least significant difference test.

at the levels of dnRXR $\alpha$ expressed, both RAR $\gamma-\operatorname{RXR} \alpha$ and $\operatorname{RAR} \gamma-\operatorname{dnRXR} \alpha$ were present in keratinocyte nuclei of the transgenic mouse epidermis with RAR $\gamma-\operatorname{dnRXR} \alpha$ being predominant.

\section{Discussion}

Previous studies of knockout mice mutated in the RXR $\alpha$ gene have not revealed its role in skin development and homeostasis because of early embryo lethality (for review, see Kastner et al. 1995). Also, analysis of the RXR $\beta$ knockout mice did not reveal any skin abnormalities probably because of the predominant presence of func- tionally redundent $\mathrm{RXR} \alpha$ in this tissue (Kastner et al. 1996). In this study, our K10-dnRXR $\alpha$ mouse model provides for the first time biological evidence that RXR $\alpha$ is involved in RAR-dependent regulation of gene expression and cell proliferation and differentiation by retinoids in adult epidermis in vivo.

In vitro studies have shown previously that overexpressed RXR-RXR and/or RAR-RXR are able to regulate reporter genes containing RAREs of types DR1 and DR2 from mouse CRABPII, CRBPI, or CRBPII genes (Smith et al. 1991; Durand et al. 1992; Nakshatri and Chambon 1994). In this study, we found that RAR-selective ligands tRA and CD367, but not RXR-selective ligand SR11237, can induce CRABPII, CRBPI, and CRBPII mRNA in mouse epidermis in vivo. This finding indicates that the RAR-dependent, but not the RXR-dependent pathways mediate the retinoid regulation of these genes. It also excludes the possibility that the tRA effects are mediated by unidentified RXR-RXR as a result of conversion of tRA to 9cRA in this tissue. Interestingly, we observed a CD367-SR11237 synergism on the CRBPI gene, which contains a DR2 only. This synergism clearly indicates the presence of the RAR-RXR activity in this tissue. However, no SR11237 effects were observed with CRABPII and CRBPII genes, which contain RAREs of both type DR1 and DR2. Thus, the question remained as to whether in epidermis RXRs broadly participate in regulation of gene transcription by RAR-specific retinoids. In vitro studies have shown that binding of ligands to the RAR partner is predominant and is required for RARRXR to trans-activate RAREs of most DR types. In the absence of RAR ligands, the RXR partner in RAR-RXR bound to certain RAREs, such as DR5 from the hRAR 32 promoter, is silent in ligand binding and trans-activation (Kurokawa et al. 1994; Forman et al. 1995). Therefore, use of RXR-specific agonists alone in animal tissues in vivo would not permit elucidation of the role of RXRs in regulation of certain endogenous genes. Using immunological gel mobility shift assays, we showed that endogenous $\operatorname{RAR} \gamma$ and $\operatorname{RXR} \alpha$, the two predominant retinoid receptors in mouse epidermis, bound to RAREs as heterodimers but not homodimers (Fig. 7) even when DR1 was used as a probe (data not shown). We also showed that expression of $\operatorname{dnRXR} \alpha$ lacking AF-2 in suprabasal keratinocytes impaired the induction of CRABPII, CRBPI, and CRBPII mRNA by RAR-selective ligands. Furthermore, dnRXR $\alpha$ also reduced the CD367-SR11237 synergism on CRBPI.

Together these data strongly suggest that in suprabasal keratinocytes RAR-RXR is responsible for the action of RAR ligands on these genes and that the predominant formation of the heterodimers is likely determined by relative levels of RAR $\gamma$ versus RXR $\alpha$. As indicated by our in vitro DNA-binding study, $\operatorname{dnRXR} \alpha$ retains its function in dimerization and DNA-binding. Therefore, it most likely dimerizes with endogenous RAR $\gamma$ in competition with endogenous wild-type RXR $\alpha$ in epidermis. The resulting RAR $\gamma-\operatorname{dnRXR} \alpha$ heterodimers compete with the remaining $\mathrm{RAR} \gamma-\mathrm{RXR} \alpha$ heterodimers for binding to RAREs. This interpretation is supported by our 


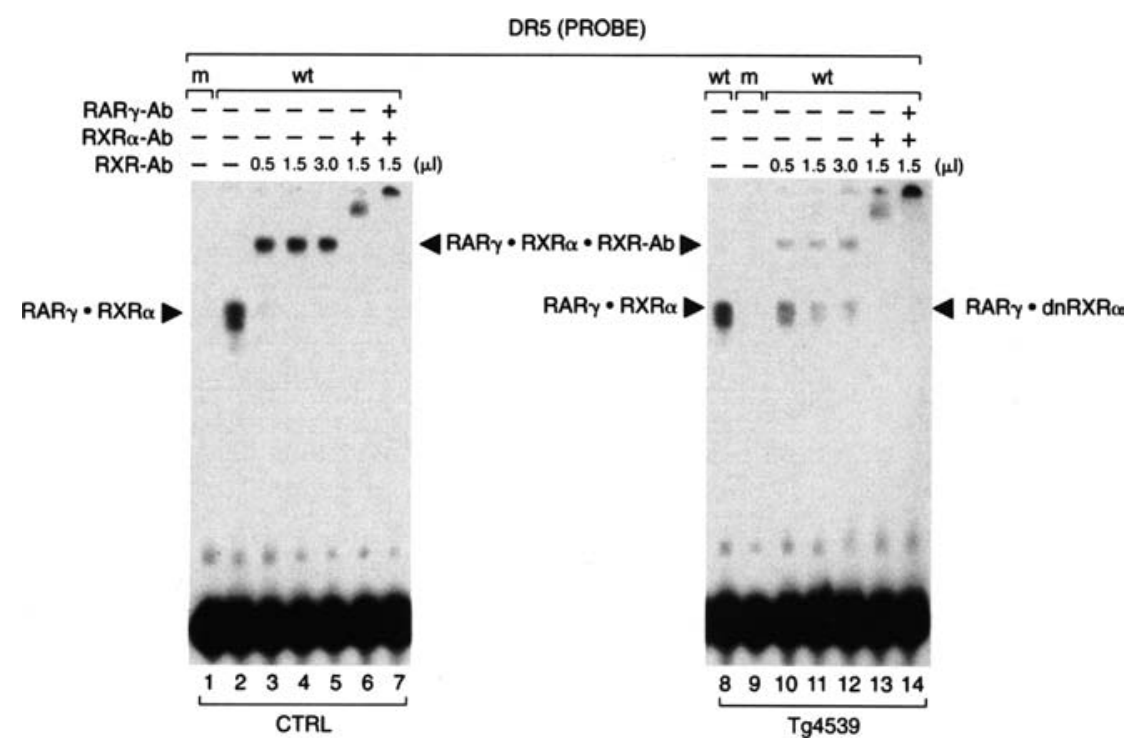

Figure 7. Immunological gel mobility shift analysis of $\operatorname{dnRXR} \alpha$ expressed in epidermis of transgenic mice. Epidermal nuclear extracts $(6 \mu \mathrm{g})$ from normal control mice (CTRL, lanes 1-7) or $\operatorname{dnRXR} \alpha$ mice (Tg4539, lanes 8-14) were incubated with ${ }^{32}$ P-labeled probes containing wild-type (wt) or mutated (m) DR5 as indicated at the top. Antibodies RXR-Ab $(0.5-3.0 \mu \mathrm{l})$, $\operatorname{RXR} \alpha-\mathrm{Ab}(1.5 \mu \mathrm{l})$, and $\operatorname{RAR} \gamma-\mathrm{Ab}(1.5 \mu \mathrm{l})$ were added postincubation as shown immediately above the gels. Types of receptor dimeric complexes identified by antibody supershifting are labeled on both sides of the gels. antibody supershifting experiment with nuclear extracts prepared directly from the $\operatorname{dnRXR} \alpha$ mouse epidermis (Fig. 7). Upon binding, RAR $\gamma-\operatorname{dnRXR} \alpha$ most likely does not stimulate transcription of target genes as effectively as RAR $\gamma-\mathrm{RXR} \alpha$ in response to RAR ligands. Consequently, it reduces the retinoid effects on gene transcription. It is noteworthy that DNA-bound RAR $\gamma-R X R \alpha$ and RAR $\gamma-\operatorname{dnRXR} \alpha$ react differently with monoclonal antibody RXR-Ab. This phenomenon indicates that the conformation of $\operatorname{RAR} \gamma-\mathrm{dnRXR} \alpha$ is different from that of RAR $\gamma-\operatorname{RXR} \alpha$ because of the absence of RXR $\alpha$ AF- 2 . Therefore, reduction by $\operatorname{dnRXR} \alpha$ of the RAR-selective ligand effects on gene transcription in vivo may reflect that RXR AF-2 is required for RAR-liganded RAR-RXR to maintain certain conformation necessary for efficiently interacting with transcriptional coactivators. On the other hand, we cannot exclude the possibility that together with liganded RAR AF-2, the AF-2 of unliganded RXR $\alpha$ directly participates in interaction between heterodimers and coactivators.

It has been shown previously that in mouse embryonal carcinoma cell lines F9 and P19, RXR agonists synergize with RAR agonists to induce the endogenous CRABPII gene (Roy et al. 1995). In this study, we observed that in mouse epidermis, RXR-selective ligands do not synergistically enhance induction of CRABPII and CRBPII genes by a suboptimal dose of RAR-selective ligands, although a synergism on the CRBPI gene is present. In the case of the mouse RAR $\beta 2$ gene, topical retinoids do not induce its transcription in epidermis (our unpublished observation), in contrast to the F9 and P19 cells (Roy et al. 1995). Thus, regulation of gene transcription by receptor family-selective retinoids and the synergism among these retinoids appear to be both cell type- and gene-specific.

Topical treatment of normal mouse skin with pharmacological doses of tRA increases epidermal thickness, differentiated granular keratinocytes, and proliferating basal keratinocytes in epidermis (Zil 1972; Connor et al.
1986). Gendimenico et al. (1994) have shown previously that topical tRA, but not SR11237 reduced the size of utriculi, a hereditary differentiation defect in the epidermis of rhino mice. We found that in normal mouse epidermis, RAR-selective CD367, but not RXR-selective SR11237 reproduces the tRA-specific effects (J.H. Xiao, X. Feng, Z.H. Peng, W. Di, and J.J. Voorhees, in prep.), consistent with the selective activity of these retinoids on the CRABPII, CRBPI, and CRBPII genes. These observations suggest that an RAR-mediated pathway is responsible for the biological activity of retinoids in epidermis. Here again, the question of whether RXRs are involved in this pathway remained unanswered. In this study, we showed that expression of $\operatorname{dnRXR} \alpha$ in suprabasal keratinocytes significantly reduced the retinoid effects on epidermal proliferation and differentiation. Thus, this RAR-dependent pathway most likely involves RXRs in the form of RAR-RXR heterodimers. In particular, the integrity of the major trans-activating domain AF-2 of unliganded RXR $\alpha$ appears to be necessary for the heterodimers to fully mediate the epidermal responses to tRA. Significant histological changes in mouse epidermis can be observed initially on day 2 during the chronic retinoid treatment, whereas the transcriptional event exemplified by induction of CRABPII, CRBPI, and CRBPII mRNA occurs within $24 \mathrm{hr}$ after the initial topical application and persists throughout the chronic treatment. Together, these observations suggest that a transcriptional process is likely required prior to cellular changes. In the $\operatorname{dnRXR} \alpha$ mice, the residual tRA effects on epidermal proliferation and differentiation are likely caused by the residual activity of RAR $\gamma-\operatorname{dnRXR} \alpha$ and the activity of remaining endogenous $\operatorname{RAR} \gamma-\operatorname{RXR} \alpha$, in agreement with the residual induction of the retinoid-responsive genes. Although to date, no data have suggested a direct role of CRABPII, CRBPI, and CRBPII in regulation of epidermal proliferation and differentiation, the molecular mechanism governing their retinoid responsiveness 
may also apply to as yet unidentified retinoid target genes that mediate the molecular events leading to epidermal changes.

Disruption of RAR $\alpha$ and/or RAR $\gamma$ genes in mice did not affect normal skin development although overall growth deficiency, high postnatal lethality, and malformation of some other organs were observed with these mice (Kastner et al. 1995). Similar to these RAR knockout mice, our $\operatorname{dnRXR} \alpha$ mice did not display any significant abnormalities in epidermal structure or cellularity during development. Interestingly, a significant increase of resistance to tRA-induced malformations at day 8.5 or 9 postcoitus was observed with the RAR $\gamma$ knockout mice (Kastner et al. 1995). At the adult stage, skin of these mice exhibits a remarkable resistance to the systemic effects of excessive $t R A$ injected intraperitoneally such as skin scaling and hair loss (Look et al. 1995). Sucov et al. (1995) have reported that at the embryo stage, limbs of the RXR $\alpha$ knockout mice developed normally, but showed resistance to the teratogenic effects of the tRA treatment. These phenotypes are somewhat similar to the reduced proliferative response of epidermis to topical tRA in the adult dnRXR $\alpha$ mice. Thus, RAR-RXR is likely responsible for these cellular changes induced by exogenous retinoids. In the $\operatorname{dnRXR} \alpha$ mice, the residual activity of RAR $\gamma-\operatorname{dnRXR} \alpha$ and the activity of the remaining endogenous $\mathrm{RAR} \gamma-\mathrm{RXR} \alpha$ appear to be sufficient to support epidermal development and homeostasis under endogenous retinoid status.

In epidermis, keratinocytes in the basal layer undergo proliferation to give daughter cells that lose proliferative potential and subsequently undergo differentiation while ascending to suprabasal layers (Fig. 8). Growth factors and cytokines released from different epidermal cell types and other skin compartments such as dermis are thought to affect proliferation of basal keratinocytes. To assess these possibilities, expression vectors made of differentiation-specific gene promoters such as the K10 gene have been developed to target expression of growthrelated proteins to differentiated suprabasal keratinocytes. For example, expression of the HPV16 E6 and E7 oncogenes in the suprabasal keratinocytes of mouse epidermis led to overexpression of TGF $\alpha$ in these cells and concomitant hyperproliferation of basal keratinocytes (Auewarakul et al. 1994). Werner et al. (1993) have shown that suprabasal expression of a dominant-negative FGF receptor mutant caused an increase in proliferation of basal keratinocytes. Retinoids applied topically to mouse skin were shown to rapidly reach epidermal and dermal cells (Connor et al. 1985). However, it has not been made clear whether retinoids stimulate proliferation of basal keratinocytes directly via receptors within these cells or indirectly via those in suprabasal keratinocytes or dermal fibroblasts. On the other hand, the retinoid signaling pathway in basal cells may possibly coordinate with that in other cell types to produce the hyperpoliferative response. Here, we report that expression of $\operatorname{dnRXR} \alpha$ in suprabasal keratinocytes reduced the proliferative response of basal keratinocytes to topically applied RAR-selective retinoids. Thus, the biologi-

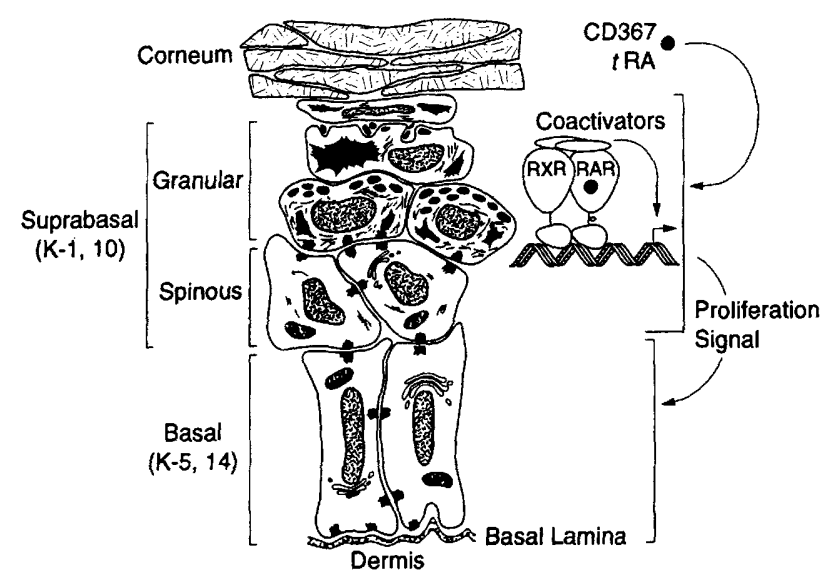

Figure 8. A proposed model for regulation of basal keratinocyte proliferation by retinoids. Structure of the epidermis is schematically depicted. Epidermal keratinocytes undergo differentiation from stem cells in the basal layer to mature corneocytes, resulting in stratum corneum. Suprabasal keratinocytes consist of spinous and granular cells, which are in the early and late stages of differentiation, respectively. The suprabasal cells express filament proteins keratin- 1 and -10 (K-1 14) instead of keratin-5 and $-14(\mathrm{~K}-5$ 14) specific to the basal cells. Topically applied retinoids activate target genes via RAR-RXR heterodimers present in the nucleus of suprabasal cells which in turn send signals to induce proliferation of the basal cells.

cal activity of RAR-RXR heterodimers in the suprabasal cells appears to regulate proliferation of basal cells. This finding suggests for the first time that via the RAR-RXRmediated pathway, retinoids induce biological changes in suprabasal keratinocytes, which in turn stimulate basal keratinocytes to proliferate by releasing as yet unidentified signaling factors and/or cell-cell contacts (Fig. 8). Further characterization of the K10- $\operatorname{dnRXR} \alpha$ mouse model will be necessary to identify molecules involved in this process. Also, expression of $\operatorname{dnRXR} \alpha$ within basal keratinocytes will be required to ascertain whether the activity of RAR-RXR heterodimers within basal cells is required for responding to the suprabasal signal.

\section{Materials and methods}

Overexpression of $R A R \gamma, R X R \alpha$, and $d n R X R \alpha$ in cultured keratinocytes

$\operatorname{RAR} \gamma, \operatorname{RXR} \alpha$, and $\operatorname{dnRXR} \alpha$ were overexpressed by transfection of cultured human epidermal keratinocytes with expression vectors pSG5-mRAR $\gamma, \mathrm{pSG} 5-\mathrm{mRXR} \alpha$, or pSG5-mRXR $\alpha \mathrm{dn}$, and nuclear extracts were prepared from these cells as described previously (Xiao et al. 1995).

\section{Immunological gel mobility shift assays}

Oligonucleotide probes containing wild-type or mutated DR5 from hRAR $\beta 2$ and wild-type DR1 from rCRBPII were described previously (Xiao et al. 1995). Sequences for probes containing wild type or mutated DR2 from the mCRBPI promoter (Smith et al. 1991) are: 5'-tcgacTTTAGTAGGTCAAAAGGTCAGACAC-3' (consensus hexameric half-sites shown in boldface capi- 
tal letters and randomly chosen nucleotides in lowercase and $5^{\prime}$-tcgacTTTAGTTTGTCAAAAGGTTGGACAC-3' (mutations underlined), respectively. Double-stranded oligonucleotide probes were $5^{\prime}$-end-labeled using $\left[\gamma^{32}\right.$ P]ATP, and immunological gel mobility shift assays were performed as described previously (Xiao et al. 1995). Antibodies used in this study were mouse monoclonal antibodies RXR-Ab (4RXID12), RXR $\alpha-A b$ (4RX3A2) (Rochette-Egly et al. 1994), and RAR $\gamma$-Ab [Abl $\gamma(A 1)]$ (Rochette-Egly et al. 1991), and a rabbit polyclonal antibody RAR-Ab [RAR $\gamma(M 454)]$ (Santa Cruz Biotechnology). Amounts equivalent to undiluted antibody fluids used in most cases were $1-2 \mu l$.

Construction of epidermis-specific expression vectors for $\operatorname{dnRXR} \alpha$ and lacZ

To construct $\mathrm{K} 10-\mathrm{dnRXR} \alpha$, a polycloning site $5^{\prime}-\mathrm{NotI}-\mathrm{Bg} \mathrm{III}$ SalI-Aval-StuI-EcoRI-HindIII-BamHI-XhoI-NotI-3' was inserted into pBlueScript SK(-) (Stratagene) between SstI and KpnI sites to give pMCS-1. A double-stranded oligonucleotide spacer was prepared by annealing oligonucleotides, 5 -TCGGAATTGTGAGCGCTCACAATTC-3' and 5'-CCGAGAATTGTGAGCGCTCACAATT-3', and inserted into the Aval site in pMCS-1 to give pLBS. Then, a 850-bp StuI-Sall fragment containing rabbit $\beta$-globin gene intron-II, a polycloning site $15^{\prime}$ EcoRI-BamHI-BgIII-3'\}, and the SV40 polyadenylation signal sequence, was isolated from pSG5 and inserted into pLBS between the Stul and Xhol sites, resulting in pLBS-2. To obtain the bovine keratin-10 (BK10) gene promoter, pCKVI-CAT was digested with Sall and XhoI (Bailleul et al. 1990). A 4.8-kb fragment containing the BK10 promoter, which extends from a SalI site to a KpnI site 20 bp downstream of the TATA box, was purified and inserted into the Sall site in pLBS-2 to give pXJ81L. Finally, a $1.5-\mathrm{kb}$ EcoRI-BglII fragment from pSG5-mRXR $\alpha \mathrm{dn}$ (Durand et al. 1992), which contains dnRXR $\alpha$ cDNA, was inserted into pXJ81L between the EcoRI and BamHI sites, resulting in pXJ81L-mRXR $\alpha \mathrm{dn}$.

To construct K10-lacZ, a 3.9-kb HindIII-Sall fragment containing the bacterial lac $Z$ gene coding sequence and the SV40 polyadenylation signal was liberated from pXJ40-lacZ (Xiao et al. 1991\}, and inserted into pLBS between HindIII and XhoI sites to give $\mathrm{pLZ}$. A $0.7-\mathrm{kb}$ StuI-HindIII fragment containing the rabbit $\beta$-globin gene intron II was isolated from p513, which is identical to pSG5 except for its polycloning site $15^{\prime}$-EcoRIBamHI-HindIII-XhoI-NotI-SmaI-PstI-SstI-KpnI-BgIII). This fragment was inserted into pLZ between the StuI and HindIII sites, resulting in pLGZ. Finally, the BK10 promoter fragment was inserted into the SaII site to give pXJ81L-lacZ.

\section{Preparation of transgenic mice}

$\mathrm{K} 10-\operatorname{dnRXR} \alpha(7.7 \mathrm{~kb})$ and $\mathrm{K} 10-1 a c Z(9.4 \mathrm{~kb})$ were liberated from plasmid vectors pXJ81L-mRXR $\alpha$ dn and pXJ81L-lacZ, respectively, by digestion with NotI, separated by electrophoresis on a $0.8 \%$ agarose gel, and purified through a Nucleobond AX20 column (The Nest Group). The purified DNA fragment was microinjected into $\mathrm{F} 2$ hybrid zygotes from C57BL/6J $\times$ SJL/J parents (the Jackson Laboratory) at a concentration $2-3 \mathrm{ng} / \mu \mathrm{l}$ (Hogan et al. 1994). After overnight incubation, the eggs which survived to the two-cell stage were transferred to day 0.5 postcoitum pseudopregnant CD-1 females (Charles River). Founder transgenic mice were mated to $\mathrm{C} 57 \mathrm{BL} / 6 \mathrm{I}$ mice to give $\mathrm{Fl}$ offspring. $\mathrm{F} 2-4$ offspring was produced by crossing F1-F3 transgenic mice with C57BL/6 I mice. The microinjection was performed by the Transgenic Animal Model Core of the University of Michigan's Biomedical Research Core Facilities. All procedures using mice were approved by the University of Michigan Committee on Use and Care of Animals, and were conducted in accord with the principles outlined in the NIH guidelines for the care and use of experimental animals.

\section{Identification of transgenic mice by PCR genotyping}

Transgenic mice carrying K10-dnRXR $\alpha$ or $\mathrm{K} 10-$ IacZ were identified by PCR genotyping of tail DNA using primers specific to the BK10 promoter, dnRXR $\alpha$ cDNA, or lacZ. Mouse tail DNA was prepared as described previously (Hogan et al. 1994). PCR amplification was carried out for 30 cycles using $200-400 \mathrm{ng}$ of tail DNA, with each cycle being at $94^{\circ} \mathrm{C}$ for $1.5 \mathrm{~min} ; 60^{\circ} \mathrm{C}$ for 2 $\min$; and $72^{\circ} \mathrm{C}$ for $3 \mathrm{~min}$.

\section{Southern blotting analysis of genomic DNA from transgenic} mice

Genomic DNA from mouse tails was digested with appropriate restriction enzymes (Sambrook et al. 1989). Digestion products were separated by agarose gel electrophoresis and transferred to Zeta-Probe GT blotting membranes (Bio-Rad). cDNA probe preparation, prehybridization, hybridization, and washing were carried out as described for Northern blotting (see below).

\section{Topical retinoid treatment}

Retinoids including tRA, CD367, and SR11237 were obtained as described previously (Xiao et al. 1995). Adult mice (6-8 weeks old) were fed with laboratory rodent diet \#5001 (PMI Feeds Inc.). Prior to retinoid treatment, skin hairs were removed using a Golden A-5 clipper (Oster Professional Products). A single daily dose $(800 \mu \mathrm{l})$ of retinoids dissolved in $100 \%$ acetone (vehicle) was applied topically to the entire mouse skin for a period of $1(20 \mathrm{hr})$ or 4 days, which are referred to as acute or chronic treatments, respectively.

\section{cDNA probes, preparation of mouse epidermal RNA, and} Northern blotting analysis

Mouse CRABPII cDNA was provided by Dr. V. Giguere /Giguere et al. 1990). To prepare CRBPI (421 bp, positions 1-421, Smith et al. 1991), CRBPII (420 bp, positions 49-468) (Nakshatri and Chambon 1994), and $\beta$-actin (245 bp, positions 105-349) (Stratagene) cDNA, mouse epidermal RNA was reverse-transcribed and amplified using a RT-PCR kit (Stratagene) and appropriate primers. The resulting DNA fragments were subcloned into the PCRII vector (Invitrogen) and verified by sequencing. CDNA probes were labeled with $\left[\alpha-{ }^{32} \mathrm{P}\right]$-dCTP $(3000 \mathrm{Ci} / \mathrm{mmole})$ (DuPont-NEN) using a random priming kit (Life Technologies).

To prepare epidermal RNA, mice were sacrificed by cervical dislocation. Skin biopsies were taken using a keratome device with blade depth set as $0.2 \mathrm{~mm}$ to cut near the epidermisdermis junction. Epidermal biopsies were immediately snapfrozen in liquid nitrogen. Then, total RNA was prepared from epidermis using gunidine isothiocyanate followed by a $\mathrm{CsCl}$ gradient (Elder et al. 1991). Northern blotting analysis of purified epidermal total RNA was performed as described previously (Xiao et al. 1991). Autoradiography was carried out by exposing blots to Hyperfilm MP (Amersham Life Science) at $-70^{\circ} \mathrm{C}$ overnight. For quantitation of mRNA, the blots were analyzed with a PhosphorImager. mRNA signals were quantified using software ImageQuant (Molecular Dynamics), and normalized against corresponding retinoid-insensitive $\beta$-actin signals. Then, the signal values from retinoid-treated mice were converted to fold of induction over vehicle-treated mice in the same 
experiment. A different mouse in the group represents a sample number $(n)$ of one. Northern blotting data presented in this study pertain predominantly to RNA from epidermal cells as a smaller form of $\beta$-actin mRNA specifically expressed in dermal cells was not detected in epidermal RNA preparation.

Histological examination of mouse epidermis and in situ immunostaining of BrdU-labeled keratinocytes in mouse epidermis

Punch biopsies ( $4 \mathrm{~mm}$ ) were taken from the dorsal skin of mice and fixed in a $10 \%$ neutral buffered formalin solution (Biochemical Sciences). The specimens were then embedded in paraffin, sectioned at $5 \mu \mathrm{m}$, and stained with hemotoxylin-eosin by American Histolabs. Thickness of epidermal and granular keratinocyte layers was measured with an ocular micrometer at fifteen interfollicular areas for each mouse.

To detect proliferating cells in epidermis, mice were injected intraperitoneally with 5-bromo-2'-deoxyuridine (BrdU, $50 \mathrm{mg}$ per $\mathrm{kg}$ of body weight) (Sigma) after the topical retinoid treatment. After $1 \mathrm{hr}$, the mice were killed immediately by cervical dislocation, and $4 \mathrm{~mm}$ punch biopsies were taken from dorsal skin and embedded in an OCT compound, Tissue-Tek (Miles Laboratories). Frozen sections $(5 \mu \mathrm{m})$ were prepared from the specimens using a cryostat, and stained with peroxidase -conjugated monoclonal antibodies against BrdU (Boehringer Mannheim). Peroxidase activity was revealed using 3-amino-9ethylcarbazole (Sigma). The sections were then briefly counterstained with Gill's hemotoxylin (Biochemical Sciences). To determine the number of BrdU-labeled basal keratinocytes, four punch biopsies $(4 \mathrm{~mm}$ ) were taken from the dorsal skin of each treated mouse. Three frozen sections were prepared from each biopsy. The numbers of BrdU-labeled basal cells and total basal cells in each section were counted with 2-4 high power fields $\left(0.0625 \mathrm{~mm}^{2}\right)$ in interfollicular areas. For each mouse, the numbers from all four biopsies were pooled, and the percentage of the BrdU-labeled basal cells over the total basal cells ( $>800$ ) was calculated.

\section{Acknowledgments}

We thank Drs. M. Blessing for kindly providing us the bovine keratin 10 promoter, V. Giguere for mCRABPII cDNA, B. Shroot for CD367, and B. Janssen for SR11237. We are grateful to Dr. T. Saunders for preparation of transgenic mice, Dr. G. J. Fisher for helpful discussions, A. A. Bowen, N.-Z. Zhou, and L. Qin for technical assistance, L. Van Goor for illustrations, and T. Hamilton for statistical analysis. This work was supported by the Babcock Dermatological Research Fund and a grant from the Johnson \& Johnson Corporation. J.-H.X. is a recipient of Career Development Award from the Dermatology Foundation.

The publication costs of this article were defrayed in part by payment of page charges. This article must therefore be hereby marked "advertisement" in accordance with 18 USC section 1734 solely to indicate this fact.

\section{References}

Auewarakul, P., L. Gissmann, and A. Cid-Arregui. 1994. Targeted expression of the E6 and E7 oncogenes of human papillomavirus type 16 in the epidermis of transgenic mice elicits generalized epidermal hyperplasia involving autocrine factors. Mol. Cell. Biol. 14: 8250-8258.

Bailleul, B., M.A. Surani, S. White, S.C. Barton, K. Brown, M. Blessing, J. Jorcano, and A. Balmain. 1990. Skin hyperkera- tosis and papilloma formation in transgenic mice expressing a ras oncogene from a suprabasal keratin promoter. Cell 62: $697-708$.

Chambon, P. 1996. A decade of molecular biology of retinoic acid receptors. FASEB I. 10: 940-954.

Connor, M.J., M.L. Lindae, and N.J. Lowe. 1985. Pharmacokinetics of topically applied radio labeled retinoids in hairless mouse epidermis and dermis after single applications. J. Invest. Dermatol. 84: 184-186.

Connor, M.J., R.E. Ashton, and N.J. Lowe. 1986. A comparative study of the induction of epidermal hyperplasia by natural and synthetic retinoids. J. Pharmcol. Exp. Ther. 237: 31-35.

Duell, E.A., S. Kang, and J.J. Voorhees. 1996. Retinoic acid isomers applied to human skin in vivo each induce a 4-hydroxylase which inactivates only trans retinoic acid. I. Invest. Dermatol. 106: 316-320.

Durand, B., M. Saunders, P. Leroy, M. Leid, and P. Chambon. 1992. All-trans and 9-cis retinoic acid induction of CRABPII transcription is mediated by RAR-RXR heterodimers bound to DR1 and DR2 repeated motifs. Cell 71: 73-85.

Durand, B., M. Saunders, C. Gaudon, B. Roy, R. Losson, and P. Chambon. 1994. Activation function 2 (AF-2) of retinoic acid receptor and 9-cis retinoic acid receptor: Presence of a conserved autonomous constitutive activating domain and influence of the nature of the response element on AF- 2 activity. EMBO I. 13: 5370-5382.

Elder, J.T., G.J. Fisher, Q.Y. Zhang, D. Eisen, A. Krust, P. Kastner, P. Chambon, and I.J. Voorhees. 1991. Retinoic acid receptor gene expression in human skin. I. Invest. Dermatol. 96: $425-433$

Fisher, G.J. and J.J. Voorhees. 1996. Molecular mechanisms of retinoid actions in skin. FASEB I. 10: 1002-1013.

Forman, B.M., K. Umesono, J. Chen, and R.M. Evans. 1995. Unique response pathways are established by allosteric interactions among nuclear hormone receptors. Cell 81: 541550.

Gendimenico, G.J., T.B. Stim, M. Corbo, B. Janssen, and J.A. Mezick. 1994. A pleiotropic response is induced in F9 embryonal carcinoma cells and rhino mouse skin by all-transretinoic acid, a RAR receptor agonist but not by SR11237, a RXR-selective agonist. I. Invest. Dermatol. 102: 676-680.

Giguere, V., S. Lyn, P. Yip, C.H. Siu, and S. Amin 1990. Molecular cloning of cDNA encoding a second cellular retinoic acid-binding protein. Proc. Nat1. Acad. Sci. 87: 6233-6237.

Glass, C.K. 1996. Some new twists in the regulation of gene expression by thyroid hormone and retinoic acid receptors. J. Endocrin. 150: 349-357

Hogan, B., R. Beddington, F. Costantini, and E. Lacy. 1994. Manipulating the mouse embryo: A laboratory manual. Cold Spring Harbor Laboratory Press, Cold Spring Harbor, NY.

Imakado, S., J.R. Bickenbach, D.S. Bundman, J.A. Rothnagel, P.S. Attar, X.J. Wang, V.R. Walczak, S. Wisniewski, J. Pote, J.S. Gordon, R.A. Heyman, R.M. Evans, and D.R. Roop. 1995. Targeting expression of a dominant-negative retinoic acid receptor mutant in the epidermis of transgenic mice results in loss of barrier function. Genes \& Dev. 9: 317-329.

Kastner, P., M. Mark, and P. Chambon. 1995. Nonsteroid nuclear receptors: What are genetic studies telling us about their role in real life. Cell 83: 859-869.

Kastner, P., M. Mark, M. Leid, A. Gansmuller, W. Chin, J.M. Grondona, D. Decimo, W. Krezel, A. Dierich, and P. Chambon. 1996. Abnormal spermatogenesis in RXR $\beta$ mutant mice. Genes \& Dev. 10: 80-92.

Kurokawa, R., J. DiRenzo, M. Boehm, J. Sugarman, B. Gloss, M.G. Rosenfeld, R.A. Heyman, and C.K. Glass. 1994. Regulation of retinoid signaling by receptor polarity and allosteric 
control of ligand binding. Nature 371: 528-531.

Look, J., J. Landwehr, F. Bauer, A.S. Hoffmann, H. Bluethmann, and P. LeMotte. 1995. Marked resistance of RAR $\gamma$-deficient mice to the toxic effects of retinoic acid. Am. I. Physiol. (Edocrinol. Metab. 32)269: E91-99.

Mangelsdorf, D.J. and R.M. Evans. 1995. The RXR heterodimers and orphan receptors. Cell 83: 841-850.

Marks, F. and G. Furstenberger. 1993. Proliferative responses of the skin to external stimuli. Environm. Health Perspect. (Suppl. 5) 101: 95-102.

Nagpal, S., S. Friant, H. Nakshatri, and P. Chambon. 1993. RARs and RXRs: Evidence for two autonomous transactivation functions (AF-1 and AF-2) and heterodimerization in vivo. EMBO J. 12: 2349-2360.

Nakshatri, H. and P. Chambon. 1994. The directly repeated RG/G/T)TCA motifs of the rat and mouse cellular retinolbinding protein II genes are promiscuous binding sites for RAR, RXR, HNF-4, and ARP-1 homo- and heterodimers. $J$. Biol. Chem. 269: 890-902.

Peck, G.L. and I.J. Di Giovanna. 1994. Synthetic retinoids in dermatology. In The retinoids: biology, chemistry, and medicine (ed. M.B. Sporn, A.B. Roberts, and D.S. Goodman), pp. 209-286. Raven Press, New York, NY.

Pfahl, M. and F. Chytil. 1996. Regulation of metabolism by retinoic acid and its nuclear receptors. Annu. Rev. Nutr. 16: $257-283$.

Rochette-Egly, C., Y. Lutz, M. Saunders, I. Scheuer, M.P. Gaub, and P. Chambon. 1991. Retinoic acid receptor $\gamma$ : Specific immunodetection and phosphorylation. I. Cell. Biol. 115: 535-545.

Rochette-Egly, C., Y. Lutz, V. Pfister, S. Heyberger, I. Scheuer, P. Chambon, and M.P. Gaub. 1994. Detection of retinoid X receptors using specific monoclonal and polyclonal antibodies. Biochem. Biophys. Res. Commun. 204: 525-536.

Roy, B., R. Taneja, and P. Chambon. 1995. Synergistic activation of retinoic acid (RA)-responsive genes and induction of embryonal carcinoma cell differentiation by an RA receptor $\alpha(\operatorname{RAR} \alpha)$-, RAR $\beta$-, or RAR $\gamma$-selective ligand in combination with a retinoid X receptor-specific ligand. Mol. Cell. Biol. 15: 6481-6487.

Saitou, M., S. Sugai, T. Tanaka, K. Shimouchi, E. Fuchs, S. Narumiya, and A. Kakizuka. 1995. Inhibition of skin development by targeted expression of a dominant-negative retinoic acid receptor. Nature 374: 159-162.

Sambrook, J., E.F. Fritsch, and T. Maniatis. 1989. Molecular cloning: A laboratory manual Cold Spring Harbor Laboratory Press, Cold Spring Harbor, NY.

Smith, W.C., H. Nakshatri, P. Leroy, J. Rees, and P. Chambon. 1991. A retinoic acid response element is present in the mouse cellular retinol binding protein I (mCRBPI) promoter. EMBO T. 10: 2223-2230.

Sucov, H.M., J.C. Izpisua-Belmonte, Y. Ganan, and R.M. Evans. 1995. Mouse embryos lacking RXR $\alpha$ are resistant to retinoicacid-induced limb defects. Development 121: 3997-4003.

Werner, S., W. Weinberg, X. Liao, K.G. Peters, M. Blessing, S.H. Yuspa, R.L. Weiner, and L.T. Williams. 1993. Targeted expression of a dominant-negative FGF receptor mutant in the epidermis of transgenic mice reveals a role of FGF in keratinocyte organization and differentiation. EMBO T. 12: 26352643.

Xiao, J.H., I. Davidson, H. Matthes, J.M. Garnier, and P. Chambon. 1991. Cloning, expression, and transcriptional properties of the human enhancer factor TEF-1. Cell 65: 551-568.

Xiao, J.H., B. Durand, P. Chambon, and J.J. Voorhees. 1995. Endogenous retinoic acid receptor (RAR)-retinoid $X$ receptor (RXR) heterodimers are the major functional forms regulat- ing retinoid- responsive elements in adult human keratinocytes. J. Biol. Chem. 270: 3001-3011.

Zhang, X.K., G. Salbert, M.O. Lee, and M. Pfahl. 1994. Mutations that alter ligand-induced switches and dimerization activities in the retinoid $\mathrm{X}$ receptor. Mol. Cell. Biol. 14: 4311-4323.

Zil, J.S. 1972. Vitamin A acid effects on epidermal mitotic activity, thickness, and cellularity in the hairless mice. J. Invest. Dermatol. 59: 228-232. 


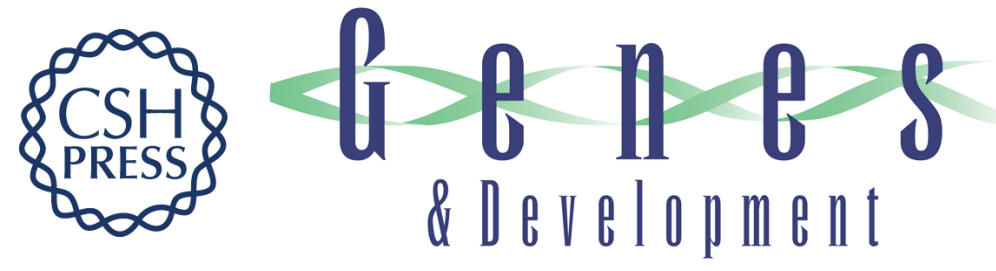

\section{Suprabasal expression of a dominant-negative RXR alpha mutant in transgenic mouse epidermis impairs regulation of gene transcription and basal keratinocyte proliferation by RAR-selective retinoids.}

X Feng, Z H Peng, W Di, et al.

Genes Dev. 1997, 11:

Access the most recent version at doi:10.1101/gad.11.1.59

References This article cites 35 articles, 12 of which can be accessed free at:

http://genesdev.cshlp.org/content/11/1/59.full.html\#ref-list-1

License

Email Alerting Receive free email alerts when new articles cite this article - sign up in the box at the top Service right corner of the article or click here.

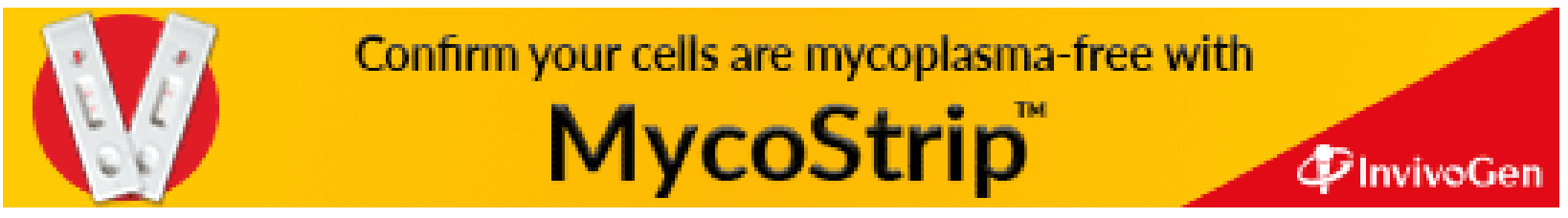

